4 Pieterjan De Bauw ${ }^{1 *}$ \& Erina Shimamura ${ }^{1 *}$, Tovohery Rakotoson ${ }^{2}$, Andry Andriamananjara ${ }^{2}$, 5 Mieke Verbeeck ${ }^{1}$, Roel Merckx ${ }^{1}$, Erik Smolders ${ }^{1}$

\section{Farm yard manure application mitigates aluminium toxicity and phosphorus deficiency for different upland rice genotypes}

\author{
${ }^{*}$ joint first authors \\ ${ }^{\delta}$ corresponding author
}

Key words: Aluminium Toxicity, Phosphorus Deficiency, Organic P Use, Farmyard Manure Application, Soil Chemical Dynamics, Mineral P, Upland Rice, Genotypic Variation

Target Journal: Journal of Agronomy and Crop Science

Running Title: Farmyard manure for rice on acid soils

${ }^{1}$ Katholieke Universiteit Leuven, Dept. of Earth and Environmental Sciences, Belgium

${ }^{2}$ Laboratoire des Radio Isotopes, BP 3383, 101 Antananarivo, Madagascar 
24 Upland rice production on acid, weathered soils is often constrained by phosphorus (P) deficiency and 25 aluminium toxicity. Farmyard manure application (FYM) can sharply enhance yields and agronomic $\mathrm{P}$ 26 fertilizer (TSP) efficiency under such abiotic stresses. We tested the hypothesis that rice genotypes differ 27 in aluminium tolerance and in the extent of using organic $P$, offering distinct benefits under TSP-FYM combinations. Multiple field trials were conducted in the uplands of Madagascar, with factorial 29 combinations of six genotypes, amendments of FYM (at a rate of 17-25 kg P ha-1 versus a zero control) 30 and TSP application (40 $\mathrm{kg} \mathrm{P} \mathrm{ha}^{-1}$ versus a zero control), with blanket N\&K additions. Rice grain yields 31 reached a maximum of $6 \mathrm{t} \mathrm{ha}^{-1}$ after three years of TSP+FYM application, with an average of $3.2 \mathrm{t} \mathrm{ha}^{-1}$ over 32 the years. Grain yields were about $1.2 \mathrm{t} \mathrm{ha-}^{-1}$ for FYM only and about $1.5 \mathrm{t} \mathrm{ha} \mathrm{a}^{-1}$ for TSP only while crops 33 failed under zero $P$ input. Genotypic effects on rice yields were much smaller than the large effects of 34 FYM, TSP, or its combination. Application of FYM increased soil $\mathrm{pH}$ and $\mathrm{CaCl}_{2}$-extractable $\mathrm{P}$ while 35 decreasing $\mathrm{CaCl}_{2}$-extractable aluminium. An additional liming trial indicated that the beneficial effects of 36 FYM over TSP relate to liming effects. The FYM application lowers aluminium toxicity which overrules 37 potential effects of organic $P$ supply. Hence, genotypic ranking of yields and agronomic efficiency was 38 inconsistent, without superior genotypes under FYM versus TSP. However, Chomrong Dhan and FOFIFA 39172 generally displayed superior yields. Chomrong Dhan is found to be more sensitive to aluminium 40 toxicity whereas FOFIFA 172 is less performant under low $\mathrm{P}$ input. Aluminium tolerance should be 41 considered when developing rice genotypes for high P efficiency in weathered soils. 
43 Upland rice is often grown by subsistence farmers in Asia, sub-Saharan Africa, and Central America; 44 however, yield gaps of rice are larger in upland compared to lowland rice cropping systems (Chauhan, 45 Jabran, \& Mahajan, 2017). A large fraction of tropical upland systems are strongly nutrient-depleted due 46 to high soil weathering, persistent soil degradation and continuous cropping without external inputs

47 (Stoorvogel et al. 1993). The weathered soils are dominated by sesquioxides which, combined with high 48 soil acidity, can cause aluminium (Al) toxicity, low phosphorus ( $\mathrm{P}$ ) availability, and hence low agronomic $\mathrm{P}$ 49 use efficiency to the rice crop (Nishigaki et al., 2019). Therefore, upland rice production is often constrained by the combination of $\mathrm{P}$ limitations and soil acidity (i.e. Al toxicity), logically aggravated by

51 drought (Diagne et al., 2013; Mueller et al., 2012). For example, upland rice production in Madagascar 52 contributes largely to the country's total rice production, but a vast amount of the available upland area 53 remains uncultivated as a result of these particular soil constraints (Andriamananjara et al., 2018; Raboin 54 et al., 2014).

55 To overcome P limitations and Al toxicity in strongly weathered, acid upland soils, relatively large amounts 56 of mineral P fertilizer are needed, which are often beyond reach to most common farmers (Nziguheba, 57 2007). Efforts are thus needed to increase the agronomic $P$ fertilizer use efficiency. This can be achieved 58 by soil management practices that increase the $\mathrm{P}$ availability to the crop, in combination with the use of 59 P-efficient genotypes (Nziguheba et al., 2016).

60 The application of organic matter (OM) can enhance soil P availability, alter soil pH and reduce Al toxicity.

61 Several field trials with upland rice showed that farmyard manure (FYM) applications in the planting holes

62 largely increase the agronomic $P$ use efficiency in fields with added N\&K fertilisers (Andriamananjara et 63 al., 2018, 2019). Organic anions released during OM decomposition compete with phosphate $\left(\mathrm{PO}_{4}\right)$ 64 sorption and improve availability of $\mathrm{P}$ from mineral $\mathrm{P}$ fertilizers (e.g. triple super phosphate (TSP)). The 
FYM applications can temporarily enhance soil pH, thereby facilitating root proliferation and plant access

66 to soil $\mathrm{P}$ while, at the same time, reducing $\mathrm{PO}_{4}$ sorption (Haynes and Mokolobate, 2001; Cong and Merckx,

67 2005). Finally, local high doses of FYM can enhance soil moisture content and reduce water stress.

68 However, none of these factors have been experimentally disentangled to explain the beneficial effects

69 on yields and $\mathrm{P}$ uptake for upland rice.

As for multiple abiotic stresses (Jagadish et al., 2012), rice breeding for P-efficient genotypes will be

71 beneficial in upland rice cropping systems. The adaptation to P-limiting environments can derive either

72 from an increased internal $P$ utilization efficiency (PUE $\left.=[\text { Plant Biomass }]^{*}[\text { Plant } P \text { Uptake }]^{-1}\right)$, i.e., how

73 efficient the plant can use its tissue $\mathrm{P}$ to grow, or from an increased $\mathrm{P}$ acquisition efficiency (PAE $=$ [Plant

74 P uptake ${ }^{*}[\text { Root biomass }]^{-1}$ ), i.e. how efficient a plant can acquire $\mathrm{P}$ from the soil (Vandamme, Rose, 75 Saito, Jeong, \& Wissuwa, 2016). (Akhtar, Oki, \& Adachi, 2008; Vandamme, Rose, et al., 2016; Vandamme, 76 Wissuwa, et al., 2016; Wissuwa \& Ae, 2001). Genotypic variation in PAE is related to a combination of 77 differences in effective root surface area per plant (Nestler \& Wissuwa, 2016) or in P acquisition strategies 78 (Clark, 1983). For example, it is well established that plants can mobilize soil-adsorbed $\mathrm{P}$ by secreting root exudates, with different underlying P-solubilisation strategies from the inorganic P pool, or that plants can access organic $P$ forms by the excretion of phosphatases (Richardson et al., 2011; Rose et al., 2013). The

81 potential role of the organic $\mathrm{P}$ pool as a source of available $\mathrm{P}$ in tropical weathered soils has been 82 emphasized in previous studies (Turner, 2006), however, information on the utilization of soil organic $\mathrm{P}$ 83 by rice is scarce. One recent isotope dilution study with rice (Rakotoson, 2014), and an older study with 84 ryegrass (Thibaud et al., 1988) and wheat (Osborne \& Rengel, 2002) suggested that plant roots can locally 85 absorb P from organic sources, likely by mineralization after phosphatase secretion or by interacting with 86 microbial communities (Mehra et al., 2017). Potentially, rice genotypes may thus differ in the extent of 87 using organic $\mathrm{P}$ and some genotypes may offer distinct benefits in FYM-TSP combinations compared to 88 TSP only. However, only limited research has been conducted to assess the interaction between upland 
rice genotypes and the supply of organic soil amendments on the agronomic efficiency of $P$ in highly

90 weathered soils.

91 The objectives of this study were to evaluate the interactions between rice genotypes and supply of FYM

92 in acid, low P soils and to identify soil chemical mechanisms explaining such interactions and ameliorating

93 the abiotic stresses related to soil acidity and low $\mathrm{P}$ availability to the rice plant. We speculated that some

94 genotypes may offer distinct benefits in FYM-TSP combinations. Multiple field trials were conducted in

95 the uplands of Madagascar, with factorial combinations of six genotypes, FYM and TSP applications with

96 blanket adequate N\&K dosing and periodic irrigation, except for the first year. Specific attention was given

97 to treatment effects on soluble $\mathrm{P}, \mathrm{Al}$, and soil $\mathrm{pH}$ by including an additional soil incubation trial and a

98 mineral lime reference field trial for all genotypes.

99

100

Materials and methods

101

\section{Summary of the experimental design}

102 Field trials with factorial combinations of genotypes (Geno) and soil amendments were performed on

103 three different, but adjacent fields with similar properties. In Field experiment 1, FYM-TSP-Geno

104 interactions were tested for three subsequent seasons spread over three years, in Field experiment 2,

105 FYM-TSP-Geno interactions for two subsequent seasons and in Field experiment 3, Lime-TSP-Geno

106 interactions for one season. This combination of field experiments and seasons is referred to as an

107 ensemble of six field trials, i.e. on three different field experiments, each over a period of, respectively, 3,

1082 , and 1 season. All plots were periodically irrigated except for the first season of field 1 . In addition, a

109 laboratory incubation trial was set up to identify soil chemical processes explaining FYM-TSP interactions

110 and to corroborate information from soil analysis of the field, sampled at the end of the field trials.

\section{$111 \quad$ Selected rice genotypes}


112 Six upland rice genotypes were selected based on their contrasting performance on low P soils and

113 differences in P acquisition capacity and efficiency (PAE). Detailed information on the selected genotypes

114 is presented in Table 1. Two genotypes with high PAE, DJ 123 and CG 14 (Koide et al., 2013; Mori et al.,

115 2016; Saito et al., 2015), and one control genotype with low performance in low P soils, NERICA 4 (De

116 Bauw et al., 2019; Koide et al., 2013; Mori et al., 2016; Pujol \& Wissuwa, 2018; Saito et al., 2015), were

117 selected. Three other genotypes, locally adopted in Madagascar (i.e. Chomrong Dhan, FOFIFA 172 and

118 FOFIFA 173) of which detailed information on their PAE is still lacking (Raboin et al., 2014), were also

119 included.

120

Field trials

121 A three-seasonal field experiment (Field experiment 1) was conducted between November and May 122 (2016-2019) at an upland site in Behenjy, located in the central highland region of Madagascar. Details on

123 the locations and standard soil characteristics are presented in Table 2. During the three consecutive

124 years, five (year 1, 2016) or six (years 2-3; 2017-2018) upland rice genotypes, two farmyard manure (FYM)

125 treatments ( 0 and $12.7,21.7$, and $10 \mathrm{t}$ dry weight FYM ha ${ }^{-1}$ respectively for each year) and two mineral $\mathrm{P}$

126 treatments (triple super phosphate (TSP); 0 and $40 \mathrm{~kg} \mathrm{P} \mathrm{ha}^{-1}$ ) were combined in a full factorial design. The

127 FYM treatments corresponded to an addition of $0,19.0,25.1$, and $17.0 \mathrm{~kg} \mathrm{P} \mathrm{ha}^{-1}$, respectively, for each

128 year as presented in Table S1 (Supplementary Information). Four large TSP $\times$ FYM treatment blocks (i.e.

129 Ctrl, FYM, TSP, TSP+FYM) were established. The selected genotypes were sown in each treatment block

130 (i.e. a nested design). All plots, including control, received $80 \mathrm{~kg} \mathrm{ha}^{-1} \mathrm{~N}$ as urea and $60 \mathrm{~kg} \mathrm{ha}^{-1} \mathrm{~K}_{\text {as }} \mathrm{K}_{2} \mathrm{SO}_{4}$.

131 The selected genotypes were sown at a planting distance of $20 \mathrm{~cm} \times 20 \mathrm{~cm}$ with two seeds per planting

132 hole. Each genotype was sown in different subplots of $1.92 \mathrm{~m}^{2}$ with 12 plants $\times 4$ rows, randomly

133 distributed within the treatment blocks. For the FYM treatments, fresh FYM was locally applied in the

134 planting hole up to approximately $5-10 \mathrm{~cm}$ depth and mixed with the soil. For the TSP treatments, granules

135 of triple super phosphate (2-4 mm diam.) were also locally applied in the planting hole up to 
approximately $2 \mathrm{~cm}$ depth and mixed with the soil. For each year, the FYM was collected from local

137 smallholder farmers; the chemical properties and corresponding nutrient doses of the applied FYM are presented in Table S1 (Supplementary Information). Plots were manually weeded. During the first year, water availability depended on natural rainfall, while the plots were irrigated after each five days without rain in year 2 (2017) and year 3 (2018) to avoid water stress masking the effects of treatments. Straw and grain yield was determined at maturity (i.e. 138-159 days after sowing (DAS) in year 1 (2016), 151 DAS in year 2 (2017), and 130-144 DAS in year 3 (2018)), omitting one border row per plot and after sample drying at $70^{\circ} \mathrm{C}$. Grain yield is reported at $14 \%$ moisture content. Straw and grain samples were ground, and composite samples of each genotype were made by combining all subplots within the treatment block for plant analysis. Soil samples were collected at the start (i.e. initial, before any treatment) and at 11 (i.e. middle) and 34 months after the first treatment application (i.e. final harvest) in Field experiment 1 (Table

147 S2, Supplementary Information) as follows. Before starting the experiment, the topsoil (0-15 $\mathrm{cm}$ depth) was randomly collected from four points covering the field site. The later soil sampling was done after dividing each treatment block into 4 subplots; the same sampling depth was used the second sampling but two soil layers (topsoil at $0-15 \mathrm{~cm}$ and subsoil at $15-30 \mathrm{~cm}$ ) were collected at the final sampling. The collected samples from the different points at time zero and from different subplots were separately 152 analysed.

The second field experiment (Field experiment 2) was initiated on a neighbouring field in 2017. This trial was repeated for two seasons, simultaneously with years 2 and 3 of Field experiment 1 . All treatments were identical as in year 2 (2017) and year 3 (2018) of the first field experiment. For this second field 156 experiment, a completely randomized design was established by including two replicate blocks of the 157 same treatments (i.e. Ctrl, FYM, TSP, TSP+FYM), each having a size of $42.2 \mathrm{~m}^{2}$. The six selected rice genotypes (Table 1) were planted in subplots which were randomly distributed within each treatment block. Plots were irrigated to field capacity after each five days without rain. All plots received $\mathrm{N}$ and $\mathrm{K}$ as 
described for Field experiment 1. At maturity, straw and grain yield determination, and $P$ analyses occurred similarly as explained for Field experiment 1 . Soil samples were collected 21 months after the first treatment application (i.e. final harvest; Table S2, Supplementary Information) in Field experiment 2, as described for Field experiment 1.

The third field experiment (Field experiment 3) was performed to test Lime-TSP-Geno interactions during one season (year $3 ; 2018$ ). This field trial was established in 2018 , having two replicate blocks at the side of Field experiment 2 , and included two liming treatments in a completely randomized block design. The combination of six rice genotypes (Table 1) and two liming treatments were randomly assigned over the two blocks. In one treatment $4 \mathrm{t} \mathrm{ha}^{-1}$ dolomite was applied (Lime), while in the other treatment $4 \mathrm{t} \mathrm{ha}^{-1}$ dolomite and $40 \mathrm{~kg} \mathrm{P} \mathrm{ha}^{-1}$ (as TSP) were amended together (Lime+TSP). All plots received $\mathrm{N}$ and $\mathrm{K}$ as described for Field experiment 1 . The dolomite was broadcasted and incorporated into the top soil at approximately $10-20 \mathrm{~cm}$ depth one week before fertilizer application and subsequent sowing. Similar grain and straw data were collected as described for Field experiment 1 and 2 . Soil samples were collected 12 months after liming (i.e. final harvest; Table S2, Supplementary Information) in Field experiment 3, as described for Field experiment 1 . Soils were collected from two subplots per treatment and analysed separately.

\section{Soil incubation experiment}

A soil incubation experiment was set up to monitor the effects of FYM on soil chemical properties, i.e. $\mathrm{pH}$ and $1 \mathrm{mM} \mathrm{CaCl}{ }_{2}$ extractable elements. Topsoil $(0-20 \mathrm{~cm})$ was collected from the side of Field experiment 1 (Table 2), air-dried and sieved (4 mm). The FYM was collected from different farmers in 2016, air-dried and ground into $0.2 \mathrm{~mm}$. Characteristics of the FYM used in this experiment are presented in Table S1 (Supplementary Information). The FYM was added at different rates (0, 2.3, 12.0, 23.5, $46.9 \mathrm{~g} \mathrm{FYM} \mathrm{kg}^{-1}$ soil; Table S1) and was homogeneously mixed with the soil. The FYM rates applied on the field ranged 
183 from 10 to 21.7 ton $\mathrm{ha}^{-1}$, and these were more or less equivalent to the intermediate FYM rates used in

184 this incubation experiment (i.e. 12 to $23 \mathrm{~g} \mathrm{FYM} \mathrm{kg}^{-1}$ ), as the FYM is mixed on the field into the $0-10 \mathrm{~cm}$ soil 185 with a bulk density of $0.98 \mathrm{~g} \mathrm{~cm}^{-3}$ (Table S1, Supplementary Information).

186 Before incubation, the soil and FYM were thoroughly mixed and the soil moisture content was adjusted 187 with distilled water to $20 \% \mathrm{w} / \mathrm{w}$. The moist soil mixtures (equivalent of 500 -g air-dried soil) were placed 188 in a 2-L tray $(19.2 \mathrm{~cm} \times 16.4 \mathrm{~cm} \times 9 \mathrm{~cm} \mathrm{ht}$. $)$ and covered by a plastic lid with pinholes to keep the incubated 189 soil aerated. These trays were subsequently placed in a dark incubation room at $25^{\circ} \mathrm{C}$. A randomized 190 complete block design was established and three tray replicates were included. These soil-FYM mixtures 191 were not disturbed or mixed during the entire incubation period, to minimize the fluctuation of soil 192 oxygen supply. The soil moisture content was maintained at $20 \% \mathrm{w} / \mathrm{w}$ by spraying distilled water once a 193 week (weight based). Samples were taken from the undisturbed soil surface immediately after mixing and 194 after $3,9,15,22,28,43,72$, and 99 days.

\section{$195 \quad$ Plant and soil analyses}

196 The total P concentrations in the shoots, grains, and FYM were analysed after digestion in concentrated $197 \mathrm{HNO}_{3}$ heated in a block digester (DigiPREP MS, SCP Science Co.) and measured by inductively coupled 198 plasma optical emission spectrometry (ICP-OES; iCAP 7000 series, Thermo Scientific Inc.). Internal plant 199 reference samples were included in every batch to control quality. Grain and shoot P in each genotype 200 was analysed as a composite sample from each treatment replicate. Total P uptake after harvest was then 201 determined by combining grain and shoot $P$.

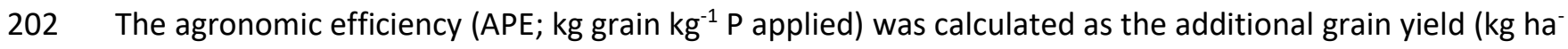

$203{ }^{1}$ ) per unit $\mathrm{P}$ applied $\left(\mathrm{kg} \mathrm{P}^{-1}\right.$ ) through either or both TSP and/or FYM, when compared to the control plot 204 (Ctrl). For the Lime+P treatment, this was also calculated in comparison with the grain yield of the Lime treatment. None of the control plots (no amendment) had rice grain yields, i.e. the second term was zero 
206 in all trials except for Field experiment 3, where rice yield was successful in the limed plots with zero P 207 input.

208 The soil $\mathrm{pH}$ and $\mathrm{CaCl}_{2}$-extractable elements were measured on an equivalent of $3 \mathrm{~g}$ air-dried soil, either

209 fresh (incubation) or air-dried (field experiments) that was suspended with $15 \mathrm{ml}$ of $1 \mathrm{mM} \mathrm{CaCl}_{2}$ solution.

210 These soil suspensions were equilibrated by end-over-end shaking $(26 \mathrm{rpm})$ for $24 \mathrm{~h}$. Next, the samples

211 were centrifuged (2000 rcf, $10 \mathrm{~min}, 20^{\circ} \mathrm{C}$ ) and the subsample of supernatant was collected. The remaining

212 samples were used for the $\mathrm{pH}$ measurement. After additional filtration $(0.45 \mu \mathrm{m})$, the total elemental

213 concentrations in the collected supernatant, further denoted as $\mathrm{CaCl}_{2}$-extractable elements, were

214 measured with inductively coupled plasma mass spectroscopy (ICP-MS; Agilent 7700x, Agilent

215 Technologies, Inc.) after acidification with $1 \% \mathrm{HNO}_{3}$. The limit of quantification for $\mathrm{P}$ was $3 \mu \mathrm{L} \mathrm{L}^{-1}$.

$216 \quad$ Statistical analysis

217 All data were subjected to analysis of variance (ANOVA) using R software, version 3.6.1 (R Development

218 Core Team, 2012). The factors genotype (Geno), FYM, TSP as well as the liming treatments in Field

219 experiment 3 were considered as fixed effects, whereas the subplot replicates were included as a random

220 effect. All field data were analysed separately per field and season, while treatment effects on yield and

221 P uptake were plotted per genotype, including the standard deviation to evaluate the genotypic ranking.

222 The coefficient of variation among genotypes was additionally calculated within each treatment

223 combination.

224 In order to evaluate the overall effects of genotype, $\mathrm{P}$ application and soil acidity and/or FYM on rice yield

225 and $\mathrm{P}$ uptake, a mixed model was fitted on the ensemble of all the seasons from the three field

226 experiments using JMP software (JMP pro 14, SAS Institute, Inc.). In this model, $Y$ (i.e. rice grain yield, total

227 P uptake, or APE) was explained as a function of total $\mathrm{P}$ applied $\left(P_{a p p l,}\right.$ in $\left.\mathrm{kg} \mathrm{P} \mathrm{ha}^{-1}\right)$ and soil acidity, i.e.

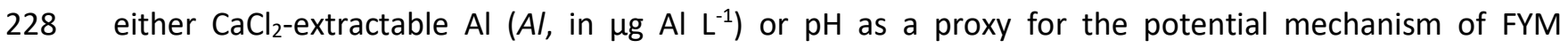


application. The year of the field trial (i.e. 2016, 2017, 2018) was added as a random variable. The model

230 reads:

231

$$
Y=\left(B_{0}+B_{0, \text { Geno }}\right)+\left(B_{1}+B_{1, \text { Geno }}\right) *\left(P_{\text {appl }}\right)+\left(B_{2}+B_{2, \text { Geno }}\right) *(A /)
$$

232 Genotype (Geno) is a categorical variable with 6 levels and assigned as the genotype-specific corrector

233 value $\left(B_{i, G e n o}, i\right.$ is 0,1 or 2$)$ to examine the overall effect of genotype and its interaction with $\mathrm{P}_{\text {appl }}$ and $\mathrm{Al}$.

234 The significance of this genotype-specific correctors denotes whether specific genotypes significantly 235 differ from the mean responses in all six field trials. In other words, specific genotypes are inherently 236 different $\left(B_{0, \text { Geno }}\right)$ or different because of its sensitivity to $\mathrm{P}$ addition $\left(\boldsymbol{B}_{1, \text { Geno }}\right)$ or to soil acidity, i.e. Al toxicity $237\left(B_{2, G e n o}\right)$. The incomplete soil sampling did not allow to link soil $\mathrm{Al}$ or $\mathrm{pH}$ data to corresponding response 238 data and only data of year 3 (i.e. topsoil at final harvest from all three fields; Table S2, Supplementary 239 Information) were used. Control yields were zero and hence these data were excluded from the modelling, 240 while the data included those of Field 3 (Lime-TSP-Geno) in order to explain the beneficial FYM effects by 241 soil analysis.

\section{$\underline{\text { Results }}$}

\section{Genotypic variation in response of rice to FYM and TSP application}

245 Rice grain yield and shoot $\mathrm{P}$ uptake largely responded to the application of FYM and TSP in both Field 246 experiments 1 and 2 in all years (Figure $1 \& 2$ ). The yield and $P$ uptake were more affected by soil 247 treatments than by genotype. Without P inputs (Ctrl), no grain yield was obtained throughout both field 248 experiments (Figure 1). In this Ctrl treatment, shoot $\mathrm{P}$ content at 80 DAS (average $0.03 \mathrm{mg} \mathrm{P}$ per shoot) 249 was half the seed P content at the start (average of $0.06 \mathrm{mg} \mathrm{P}$ per seed), confirming the extremely 250 weathered, P-deficient condition of this soil (Table 2). Rice grain yields reached $6 \mathrm{t} \mathrm{ha}^{-1}$ in year 3 (2018) 
251 (TSP+FYM) and were lowest in year 1 (2016) when no irrigation was yet adopted. The rice grain yield and 252 total $\mathrm{P}$ uptake ranked $\mathrm{FYM}+\mathrm{TSP}>\mathrm{TSP} \sim \mathrm{FYM}>\mathrm{Ctrl}$, with the FYM either above, similar, or below the TSP, 253 depending on field and year. Interestingly, the average grain yield in the TSP+FYM treatment was 254 consistently higher than the sum of the TSP and FYM treatments separately, suggesting that the effect of 255 the combined application of TSP and FYM was unlikely to be the mere P addition of each material. Similar 256 trends were observed for P uptake.

257 The effects of genotypes on grain yield and P uptake were smaller than soil treatment effects, and were 258 significant $(P<0.05)$ in four of the five trials. The interactions of these endpoints between genotypes and 259 soil treatments were significant in some, but not all trials (Figure $1 \& 2$ ). None of the genotypes 260 consistently outperformed others in terms of $\mathrm{P}$ uptake or grain yield after a FYM application compared to 261 the mineral $\mathrm{P}$ amendment. The ranking of genotypes in terms of total $\mathrm{P}$ uptake and grain yield within each 262 treatment was inconsistent over the seasons. The two tropical genotypes (i.e. DJ 123 and CG 14) were 263 generally inferior in both grain yield and total P uptake, while the control genotype NERICA 4 and FOFIFA 264173 were intermediate. The two Malagasy highland genotypes (i.e. Chomrong Dhan and FOFIFA 172) were 265 superior in all fertilizer treatments (Figures $1 \& 2$ ). Interestingly, the coefficient of variation of either grain 266 yield or $\mathrm{P}$ uptake among the genotypes within each treatment was highest in the mineral-P-amended 267 (TSP) plots compared to those the FYM- or the TSP+FYM-amended plots in four of the five trials (Figure 1

268 \& 2). This means that FYM amendment decreased the variation in grain yield and $\mathrm{P}$ uptake among 269 genotypes. The agronomic $P$ efficiency (APE) of the $P$ applied under the different treatments was 270 consistently highest for the FYM application only (FYM), and lowest for the mineral P amendment (TSP) 271 (Table 3).

272 Genotypic variation in response of rice to lime and TSP application 
273 The limed soil without $\mathrm{P}$ input (Lime) had no crop failure and the average grain yield $\left(0.6 \mathrm{t} \mathrm{ha}^{-1}\right)$, and total

$274 \mathrm{P}$ uptake $\left(0.8 \mathrm{~kg} \mathrm{P} \mathrm{ha}^{-1}\right)$ was similar to that of the FYM treatment in the first season of Field experiment 1

275 and both seasons of Field experiment 2 (Figure 1, 2, and 3). Combining TSP with lime (Lime+TSP) resulted

276 in a seven-fold increase of grain yield and a six-fold increase of total P uptake, compared to applying lime

277 only (Figure 3). These results are similar to the TSP+FYM treatment from the simultaneously conducted

278 experiment (Field experiment 2, season 2). The liming treatment showed the highest coefficient of

279 variation among genotypes within treatment, clearly due to the good performance of both Chomrong

280 Dhan and FOFIFA 173 in the limed, but strongly P-deficient subplots. This coefficient of variation was then

281 strongly reduced upon P fertilization, in combination with lime application (Figure 3). Interestingly, the

282 APE under the Lime+TSP treatment in this experiment was higher than that of the TSP+FYM treatment in

283 Field experiment 2 (Table 3).

Changes in soil properties to FYM and lime applications

285 The FYM applications to the soil in the laboratory incubation increased the soil $\mathrm{pH}$ from an initial value of 2864.3 to $4.5-6.1$, depending on the application rate. The sharp and immediate increase in pH was followed 287 by a gradual $\mathrm{pH}$ decrease but all soils amended with FYM had higher $\mathrm{pH}$ than the unamended soil (Figure 288 4A). The FYM applications increased the $\mathrm{CaCl}_{2}$-extractable $\mathrm{P}$ (Figure 4B) and decreased $\mathrm{CaCl}_{2}$-extractable 289 Al up to pH 5.0 (Figure 4C). Aluminium oxyhydroxides are amphoteric, i.e. reacting as acids and bases and 290 dissolving well in acid as in alkaline conditions (Sposito, 1996). The $\mathrm{CaCl}_{2}$-extractable $\mathrm{Al}$ exhibited such a 291 distinct amphoteric behaviour to soil $\mathrm{pH}$ and to FYM dose, i.e. soluble Al decreased at initial FYM doses 292 and increased again at the two highest FYM rates for which pH increased to 5.5 and 6.0 (Figure 4C). The $293 \mathrm{CaCl}_{2}$-extractable $\mathrm{P}$ increased with increasing FYM doses and the semi-log trend to $\mathrm{pH}$ was linear (Figure 294 4B). 
Similar, but less pronounced effects were observed in soils of the field trials. In the control treatments, the soil $\mathrm{pH}$ at final harvest decreased over time and $\mathrm{CaCl}_{2}$-extractable Al increased (Table S2,

297 Supplementary Information). In Field experiment 1, initially, both FYM and TSP treatments increased pH

298 and decreased extractable Al, while after the final harvest, only such changes were found in the FYM 299 treatments (FYM and TSP+FYM). These changes were observed in both surface and subsoils. Similar trends 300 were observed in Field experiment 2 except that the $\mathrm{pH}$ increase and extractable $\mathrm{Al}$ decrease was 301 consistently similar in all treatments. The $\mathrm{CaCl}_{2}$-extractable $\mathrm{P}$ showed a clear increase compared to the 302 control after either TSP and/or FYM application, however, no additive effect was observed in the TSP+FYM 303 treatment compared to the single TSP and FYM treatment (Table S2, Supplementary Information). Liming 304 strongly increased soil $\mathrm{pH}$ and $\mathrm{CaCl}_{2}$-extractable $\mathrm{P}$, and it strongly reduced $\mathrm{CaCl}_{2}$-extractable $\mathrm{Al}$, even in 305 the subsoil (Table S2, Supplementary Information). Both liming treatments (Lime \& Lime+TSP)resulted in 306 the highest $\mathrm{CaCl}_{2}$-extractable $\mathrm{P}$ concentrations of all treatments, taking to account that samples were 307 taken only 12 months after application. The $\mathrm{CaCl}_{2}$-extractable $\mathrm{P}$ in these soils was never above $25 \mu \mathrm{g} \mathrm{L} \mathrm{L}^{-1}$ 308 whereas $100 \mu \mathrm{g} \mathrm{P} \mathrm{L}^{-1}$ is considered as a threshold for adequate P supply (De Bauw et al., 2019; Six et al., 309 2014).

\section{Overall genotypic effects to $P$ addition and soil acidity}

311 Equation (1) was fitted to the ensemble of six field trials and revealed the contribution of Geno, P 312 application, and soil acidity to the overall crop responses (Table 4 and Table S3). Including either soil pH 313 or $\mathrm{CaCl}_{2}$-extractable Al similarly explained grain yield, $\mathrm{P}$ uptake, and APE. Only the Al-based data, rather 314 than soil $\mathrm{pH}$, were further used to indicate effects of Al toxicity. The overall variation in rice grain yield 315 explained by soil and genotypic factors rank $\mathrm{P}$ addition $>>$ genotype > soil acidity $>$ genotype interaction 316 with P addition or soil acidity (Table 4). By including the zero-yielding control, the effects of genotype 317 became even smaller in the mixed models (details not shown). 
318 The model was extended to test whether the FYM application also affected crop response beyond its

319 effect on reducing soil acidity. This was done by extending Eqn. (1) with the added FYM dose and its 320 interaction with Geno for all field data of year 3, i.e. the TSP-FYM data of Fields 1 \& 2 and the Lime trial of

321 Field 3. This model showed that FYM had no statistically significant effect on grain yield after correcting

322 for the effects of $P$ input and reducing soil acidity. This suggests that the main effect of FYM on rice yield 323 and $\mathrm{P}$ uptake follows from its effect on soil acidity and Al toxicity.

324 In the ensemble of these data, genotypes Chomrong Dhan and FOFIFA 172 performed significantly 325 superior whereas DJ 123 and CG 14 were significantly lower (Table 4 and Table S3). The genotype-specific 326 corrector values for either $\mathrm{P}$ addition or $\mathrm{CaCl}_{2}$-extractable $\mathrm{Al}$ suggest that FOFIFA 172 is more responsive 327 to $\mathrm{P}$ addition than Chomrong Dhan and that the latter is more sensitive to Al (Table S3). That is also clearly 328 visualized in the liming trial where Chomrong Dhan performs well under low P after lifting the soil acidity 329 constraint (Figure 3 versus Figure 2).

331 Discussion

Yield and $P$ uptake of upland rice genotypes after FYM application

333 This study could not identify genotypes that consistently outperform others after the application of 334 organic matter, in contrast to only mineral P amendments, or vice versa. The main significant effects of 335 genotypes (Table 4) are more affected by their growth potential, i.e. under TSP+FYM application, rather 336 than by their inherent differences in PAE and PUE that exist among rice genotypes (De Bauw et al., 2019; 337 Nestler and Wissuwa, 2016; Vandamme et al., 2016a). This indicates that genotype selection likely 338 becomes inferior to management options when soil limitations are very severe. It is interesting that the 339 coefficient of variation of yield and P uptake generally decreases after FYM application compared to 340 mineral P amendment only (Figures 1 \& 2), and that it further decreases for yield when combining FYM 
341 with a mineral $\mathrm{P}$ amendment. This can be explained by the fact that the genetic variability under a mineral

$342 \mathrm{P}$ amendment includes sensibility of rice genotypes to multiple factors (e.g. low $\mathrm{pH}, \mathrm{Al}$ toxicity, $\mathrm{P}$ 343 deficiency, cold tolerance), while FYM application ameliorates Al toxicity (Haynes \& Mokolobate, 2001). 344 However, when only FYM is applied, the genotypic variation still includes tolerance to P deficiency. Hence, 345 when both FYM and mineral P are combined, yields are closer to their potential, with fewer environmental 346 limitations contributing to the genotypic variation (i.e. cold tolerance) (Abera et al., 2020; Raboin et al., 347 2014). Under combined TSP and FYM amendments, the genotypes Chomrong Dhan and FOFIFA 172 348 generally outperformed other tested genotypes in terms of yields. This can be explained by their improved 349 tolerance to cold conditions, and possibly explaining why these genotypes are widely adopted by 350 Malagasy farmers (Raboin et al., 2014). Additionally, it was suggested that Chomrong Dhan has a high 351 PAE, as it gives high grain yields under low input system (Raboin et al., 2014) However, such a high P 352 acquisition under P limitations could not consistently be confirmed for Chomrong Dhan in this study. The 353 multivariate model Eqn (1) fitted to the ensemble of data allows to interpret the genotypic variation and 354 its interaction with treatments, i.e. quantify the so-called $G \times E$ interactions (Table S3, Supplementary 355 Information). This showed that the most performant genotype (Chomrong Dhan) is the most sensitive to 356 soil acidity whereas the other performant genotype, FOFIFA 172, is relatively more tolerant. Conversely, 357 the responsiveness to $\mathrm{P}$ input is in the reverse order, i.e. FOFIFA 172 is more responsive (less performant 358 under low P input) than Chomrong Dhan.

359 The generally P-efficient genotype DJ 123, known for its good performance on low P soils (Mori et al., 360 2016; Nestler \& Wissuwa, 2016; Vandamme, Wissuwa, et al., 2016), was not high yielding in the low P 361 environment of this study and it even showed comparable or lower yields than the generally P-inefficient 362 rice genotype, NERICA 4. Hence, this indicates that this P-efficient genotype (DJ 123) is likely not adapted 363 to the cold highlands of Madagascar while NERICA 4 seems somehow more robust in such environment, 364 as this genotype was indeed previously classified as moderately tolerant to cold stress (Wainaina et al., 
2015). It was previously also observed that DJ 123 was extremely sensitive to Al toxicity (Famoso et al.,

366 2011), while NERICA 4 was more moderately tolerant (Kang et al., 2012). However, no such differences in

367 Al sensitivity among these genotypes were found here as judged from the statistical analysis (Table S3,

368 Supplementary Information).

Effects of FYM application on $P$ and $A /$ dynamics in weathered soils and implications for rice yields and $P$

uptake

371 This study demonstrates that FYM application improves yields up to above $5 \mathrm{t} \mathrm{ha}^{-1}$ when additionally

372 amended with mineral $P$ fertilizer, and positive interactions between FYM and TSP were found. The

373 benefits of FYM applications confirmed earlier data for rice (Andriamananjara et al., 2018; Haefele et al.,

374 2006; Satyanarayana et al., 2002), however, the mechanisms were never confirmed. Andriamananjara et

375 al. (2018) suggested that the benefits of FYM application to weathered upland soils relate to the better

376 water supply or reduced Al toxicity. By including irrigation here in years $2 \& 3$ of the study, the effect of

377 FYM on water availability was excluded. This study now confirms that the application of FYM initially

378 increases soil $\mathrm{pH}$, which concomitantly reduces soluble $\mathrm{Al}$ and increases $\mathrm{P}$ availability. An initial strong

379 liming effect of FYM application is observed in the soil incubation trial (Figure 4) but, interestingly, on the

380 field these liming effects of FYM application on soil pH are much smaller on the longer term (Table S2,

381 Supplementary Information). This suggests that the initial pH increase over the first two or three months

382 of residue decomposition (Haynes \& Mokolobate, 2001) is followed by a fast pH decrease resulting from

383 mineralisation processes, i.e. nitrification, and subsequent leaching of nitrates and/or neutral cations on

384 the field (Rowell, 2014). These observations confirm that pH effects after FYM application are indeed local

385 and short-term (Cong \& Merckx, 2005), leaving a short-term window of opportunity for crop production.

386 In contrast to the short-term pH effects, the reduced Al and increased P availability after FYM application

387 are more sensitive indices of a longer-term liming effect because small pH changes in the range 4-5 affect

388 soluble Al by over one order of magnitude (Figure 4B). The amphoteric behaviour of Al solubility likely 
indicates the trend of reduced $\mathrm{Al}^{3+}$ in the most acidic part followed by solubilisation of $\mathrm{Al}$ complexed with

390 dissolved organic matter at high FYM doses and higher pH (Sposito, 1996). The increased P availability on

391 the longer term after FYM application likely follows from (i) ligand exchange (i.e. organic sorbates

392 competing with $\mathrm{P}$ for mineral binding sites), and, (ii) the slow release of organic $\mathrm{P}$ by mineralization (Guppy

393 et al., 2005; Pypers et al., 2005).

394 Here, we now argue that the positive FYM-TSP interaction effects in acid upland soils are related to 395 mitigated Al toxicity. This is supported by the inclusion of a liming field trial and the statistical observation 396 that soluble $\mathrm{Al}$ and $\mathrm{P}$ dose explain crop response, i.e. that the FYM dose does not further explain the 397 effects across trials with lime and FYM. The local and short-term pH increase after FYM application and 398 the associated reduction in Al toxicity increase the P uptake from the TSP granules (Andriamananjara et 399 al., 2018; Cong \& Merckx, 2005). This improves initial root proliferation during seedling establishment, 400 thereby further enhancing later root growth, P uptake, plant establishment, and final yield. A hydroponic

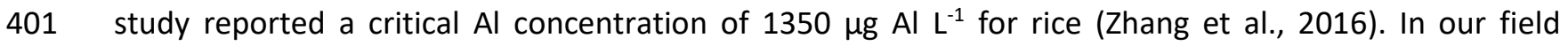
402 experiments, the measured $\mathrm{CaCl}_{2}$-extractable $\mathrm{Al}$ generally exceeded this limit, but the concentration 403 tended to be lower after FYM, TSP, or lime application, hence enabling rice yields (Table S2, Supporting 404 Information). These observations indeed validate the hypothesis that Al toxicity plays a critical role in such 405 P deficient, weathered soils.

406 The agronomic consequences of FYM applications and implications to field management

407 Rice genotype selection is thus inferior to soil management effects on acid, weathered soils when 408 considering yields. However, depending on the environment, selecting cold-, drought-, and/or disease409 tolerant genotypes can help further improve the yield potential after tackling soil limitations by additions 410 of FYM and TSP. It is striking that attempting rice cultivation on such acid soils without FYM or mineral P 411 amendments (i.e. control treatment) even further decreases soil $\mathrm{pH}$ and increases $\mathrm{Al}$ in soil solution 412 compared to the initial condition (Table S2, Supplementary Information). This is explained by (i) the 
413 natural tendency for soil acidification over time, (ii) an increased aeration and enhanced microbial activity

414 due to soil cultivation, and (iii) the nitrification of the applied urea (Rowell, 2014). Farmers should

415 recognize that cultivation and application of urea on such already acid soils, without other amendments

416 further aggravates Al toxicity to the rice plant.

417 This work clearly demonstrates how liming facilitates rice cultivation on highly weathered soils, but

418 without additional nutrient inputs yields remain very low (Figure 3). Liming only is not a sustainable way

419 to increase upland rice production, while liming combined with mineral P amendments can quickly and

420 strongly increase rice yields. It should, however, be regarded that both lime and TSP are often beyond

421 reach of farmers, following market availability and costs (AGRA, 2019; Chianu et al., 2012; Raboin et al.,

422 2016).

423 As FYM is often more easily accessible to farmers, the application of FYM forms a huge opportunity to

424 more sustainably increase rice yields on weathered, acid, low P soils. However, in order to obtain short-

425 term soil $\mathrm{pH}$ effects on the field, this work indicates that rates of at least $10 \mathrm{tha} \mathrm{h}^{-1}$ of FYM are required

426 (Figure 4), or farmers should strongly concentrate the FYM in the planting hole to facilitate local pH effects

427 close to the seedling. Applying FYM to uncultivatable fields enables rice production, but rice yields still

428 remain very low (below $2 \mathrm{t} \mathrm{ha}^{-1}$ even after three years of FYM application), due to remaining $\mathrm{P}$ limitations.

429 This is because the applied P in the FYM is not readily available to the plant and large portions of the FYM-

430 derived $\mathrm{P}$ is immobilized to the soil. Therefore, it was stated before and confirmed here that the use of

431 organic amendments alone are unlikely to overcome P deficiency in such strongly depleted soils

432 (Andriamananjara et al., 2018; Nziguheba, 2007; Nziguheba et al., 2016). Hence, the combination of

433 organic resources with mineral fertilizers would offer a more sustainable way for increasing soil fertility

434 and rice production, while reducing the use of often inaccessible mineral fertilizer. (Buresh et al., 1997;

435 Chivenge et al., 2009; Nziguheba et al., 2016; Six et al., 2014). 


\section{Conclusions}

438 This study demonstrated how FYM application ameliorates Al toxicity and P deficiency in severely 439 weathered upland soils by altering the dynamics in soil chemistry. The FYM amendment initially and 440 temporary increases soil $\mathrm{pH}$, which concomitantly reduces soluble $\mathrm{Al}$ and increases $\mathrm{P}$ availability. In 441 contrast to this short-term pH effect of FYM application, Al toxicity is ameliorated on the longer term.

442 On the longer term, P limitations can, however, not be overcome by FYM amendments only. Hence the 443 combination of FYM with TSP amendments forms a huge opportunity to ameliorate $\mathrm{P}$ limitations and Al 444 toxicity, thereby strongly improving the phosphate fertilizer use efficiency.

445 This study could not confirm the hypothesis that genotypic differences exist in organic P use efficiency for 446 rice. Further research is needed to confirm the existence of such genotypic variation in organic P cycling 447 after amendments of organic matter.

448 Finally, rice genotype selection is inferior to the effects on yield by FYM or TSP application, or the 449 combination, when the soil is highly weathered and acidic. However, two performant rice genotypes could 450 indeed be identified for such low P environments (i.e. Chomrong Dhan and Fofifa 172). In addition, this 451 study suggests that Chomrong Dhan is more sensitive to soil acidity whereas FOFIFA 172 is less performant 452 under low $\mathrm{P}$ input. To conclude, Al toxicity should be considered when breeding new rice genotypes for 453 low P environments.

\section{Acknowledgements}

456 This work was financed by a C1 project (C16/15/042), funded by KU Leuven. We thank Maarten Everaert, 457 Mino Nandrianina Rakotonandrasana, Tsanta Raharijaona, and Seheno Rinasoa for their assistance during 
staff who assisted in this work. We are grateful to Karlien Cassaert for the assistance in administration.

\section{$\underline{\text { References }}$}

Abera, B. B., Stuerz, S., Senthilkumar, K., Cotter, M., Rajaona, A., \& Asch, F. (2020). Season-specific varietal management as an option to increase rainfed lowland rice production in East African high altitude cropping systems. Journal of Agronomy and Crop Science, 206(4), 433-443. doi: 10.1111/jac.12418

AGRA. (2019). Feeding Africa's soils: Fertilizers to support Africa's agricultural transformation. Nairobi, Kenya.

Akhtar, M. S., Oki, Y., \& Adachi, T. (2008). Genetic Variability in Phosphorus Acquisition and Utilization Efficiency from Sparingly Soluble P-Sources by Brassica Cultivars under P-Stress Environment. Journal of Agronomy and Crop Science, 194(5), 380-392. doi: 10.1111/j.1439-037X.2008.00326.x

Andriamananjara, A., Rakotoson, T., Razanakoto, O. R., Razafimanantsoa, M.-P., Rabeharisoa, L., \& Smolders, E. (2018). Farmyard manure application in weathered upland soils of Madagascar sharply increase phosphate fertilizer use efficiency for upland rice. Field Crops Research, 222, 94-100. doi: 10.1016/j.fcr.2018.03.022

Andriamananjara, Andry, Rakotoson, T., Razafimbelo, T., Rabeharisoa, L., Razafimanantsoa, M.-P., \& Masse, D. (2019). Farmyard manure improves phosphorus use efficiency in weathered P deficient soil. Nutrient Cycling in Agroecosystems. doi: 10.1007/s10705-019-10022-3

Buresh, R. J., Sanchez, P. A., Calhoun, F., Palm, C. A., Myers, R. J. K., \& Nandwa, S. M. (1997). Combined Use of Organic and Inorganic Nutrient Sources for Soil Fertility Maintenance and Replenishment. doi: 10.2136/sssaspecpub51.c8

Chauhan, B. S., Jabran, K., \& Mahajan, G. (Eds.). (2017). Rice Production Worldwide. doi: 10.1007/978-3-31947516-5

Chianu, J. N., Chianu, J. N., \& Mairura, F. (2012, April). Mineral fertilizers in the farming systems of sub-Saharan Africa. A review. Agronomy for Sustainable Development, Vol. 32, pp. 545-566. doi: 10.1007/s13593-0110050-0

Chivenge, P., Vanlauwe, B., Gentile, R., Wangechi, H., Mugendi, D., van Kessel, C., \& Six, J. (2009). Organic and mineral input management to enhance crop productivity in central Kenya. Agronomy Journal, 101(5), 12661275. doi: 10.2134/agronj2008.0188x

Clark, R. B. (1983). Plant genotype differences in the uptake, translocation, accumulation, and use of mineral elements required for plant growth. Plant and Soil, Vol. 72, pp. 175-196. doi: 10.2307/42935183

Cong, P. T., \& Merckx, R. (2005). Improving phosphorus availability in two upland soils of Vietnam using shape Tithonia diversifolia H. Plant and Soil, 269(1-2), 11-23. doi: 10.1007/s11104-004-1791-1

De Bauw, P., Vandamme, E., Lupembe, A., Mwakasege, L., Senthilkumar, K., \& Merckx, R. (2019). Architectural root responses of rice to reduced water availability can overcome phosphorus stress. Agronomy, 9(1). doi: 10.3390/agronomy9010011

De Bauw, Pieterjan, Vandamme, E., Lupembe, A., Mwakasege, L., Senthilkumar, K., \& Merckx, R. (2019). Architectural Root Responses of Rice to Reduced Water Availability Can Overcome Phosphorus Stress. Agronomy, 9(1), 11. doi: 10.3390/agronomy9010011

Diagne, A., Alia, D. Y., Amovin-Assagba, E., Wopereis, M. C. S., Saito, K., \& Nakelse, T. (2013). Farmer perceptions of the biophysical constraints to rice production in sub-Saharan Africa, and potential impact of research. In Realizing Africa's rice promise (pp. 46-68). doi: 10.1079/9781845938123.0046

Famoso, A. N., Zhao, K., Clark, R. T., Tung, C. W., Wright, M. H., Bustamante, C., ... McCouch, S. R. (2011). Genetic architecture of aluminum tolerance in rice (oryza sativa) determined through genome-wide association analysis and qtl mapping. PLoS Genetics, 7(8). doi: 10.1371/journal.pgen.1002221

Guppy, C. N., Menzies, N. W., Moody, P. W., \& Blamey, F. P. C. (2005, January 1). Competitive sorption reactions between phosphorus and organic matter in soil: A review. Australian Journal of Soil Research, Vol. 43, pp. 189-202. doi: 10.1071/SR04049 
Haefele, S. M., Naklang, K., Harnpichitvitaya, D., Jearakongman, S., Skulkhu, E., Romyen, P., ... Wade, L. J. (2006). Factors affecting rice yield and fertilizer response in rainfed lowlands of northeast Thailand. Field Crops Research, 98(1), 39-51. doi: 10.1016/j.fcr.2005.12.003

Haynes, R. J., \& Mokolobate, M. S. (2001). Amelioration of Al toxicity and P deficiency in acid soils by additions of organic residues: a critical review of the phenomenon and the mechanisms involved. In Nutrient Cycling in Agroecosystems (Vol. 59).

ISO. (2007). ISO 23470:Soil quality - Determination of effective cation exchange capacity (CEC) and exchangeable cations using a hexamminecobalt trichloride solution. Retrieved from https://www.iso.org/obp/ui/\#iso:std:iso:23470:ed-1:v1:en

IUSS Working Group WRB. (2015). World reference base for soil resources, update 2015 International soil classification system for naming soils and creating legends for soil maps. Rome.

Jagadish, S. V. K., Septiningsih, E. M., Kohli, A., Thomson, M. J., Ye, C., Redoña, E., ... Singh, R. K. (2012). Genetic Advances in Adapting Rice to a Rapidly Changing Climate. Journal of Agronomy and Crop Science, 198(5), 360-373. doi: 10.1111/j.1439-037X.2012.00525.x

Kang, D.-J., Futakuchi, K., Seo, Y.-J., Vijarnsorn, P., \& Ishii, R. (2012). Evaluation of Al-tolerance on upland and lowland types of NERICA lines under hydroponic conditions. Journal of Crop Science and Biotechnology, 15(1), 25-31. doi: 10.1007/s12892-011-0083-6

Koide, Y., Pariasca Tanaka, J., Rose, T., Fukuo, A., Konisho, K., Yanagihara, S., ... Wissuwa, M. (2013). Qtls for phosphorus deficiency tolerance detected in upland nerica varieties. Plant Breeding, 132(3), 259-265. doi: 10.1111/pbr.12052

Mehra, P., Pandey, B. K., \& Giri, J. (2017). Improvement in phosphate acquisition and utilization by a secretory purple acid phosphatase (OsPAP21b) in rice. Plant Biotechnology Journal, 15(8), 1054-1067. doi: 10.1111/pbi.12699

Mori, A., Fukuda, T., Vejchasarn, P., Nestler, J., Pariasca-Tanaka, J., \& Wissuwa, M. (2016). The role of root size versus root efficiency in phosphorus acquisition in rice. Journal of Experimental Botany, 67(4), 1179-1189. doi: 10.1093/jxb/erv557

Mueller, N. D., Gerber, J. S., Johnston, M., Ray, D. K., Ramankutty, N., \& Foley, J. A. (2012). Closing yield gaps through nutrient and water management. Nature, 490(7419), 254-257. doi: 10.1038/nature11420

Nestler, J., \& Wissuwa, M. (2016). Superior Root Hair Formation Confers Root Efficiency in Some, But Not All, Rice Genotypes upon P Deficiency. Frontiers in Plant Science, 7, 1935. doi: 10.3389/fpls.2016.01935

Nishigaki, T., Tsujimoto, Y., Rinasoa, S., Rakotoson, T., Andriamananjara, A., \& Razafimbelo, T. (2019). Phosphorus uptake of rice plants is affected by phosphorus forms and physicochemical properties of tropical weathered soils. Plant and Soil, 435(1-2), 27-38. doi: 10.1007/s11104-018-3869-1

Nziguheba, G. (2007). Overcoming phosphorus deficiency in soils of Eastern Africa: recent advances and challenges. In Advances in Integrated Soil Fertility Management in sub-Saharan Africa: Challenges and Opportunities (pp. 149-160). doi: 10.1007/978-1-4020-5760-1_13

Nziguheba, G., Zingore, S., Kihara, J., Merckx, R., Njoroge, S., Otinga, A., ... Vanlauwe, B. (2016). Phosphorus in smallholder farming systems of sub-Saharan Africa: implications for agricultural intensification. Nutrient Cycling in Agroecosystems, 104(3), 321-340. doi: 10.1007/s10705-015-9729-y

Osborne, L. D., \& Rengel, Z. (2002). Growth and P uptake by wheat genotypes supplied with phytate as the only P source. Australian Journal of Agricultural Research, 53(7), 845-850. doi: 10.1071/AR01102

Pujol, V., \& Wissuwa, M. (2018). Contrasting development of lysigenous aerenchyma in two rice genotypes under phosphorus deficiency. BMC Research Notes, 11(1), 60. doi: 10.1186/s13104-018-3179-y

Pypers, P., Verstraete, S., Thi, C. P., \& Merckx, R. (2005). Changes in mineral nitrogen, phosphorus availability and salt-extractable aluminium following the application of green manure residues in two weathered soils of South Vietnam. Soil Biology and Biochemistry, 37(1), 163-172. doi: 10.1016/j.soilbio.2004.06.018

$\mathrm{R}$ Development Core Team. (2012). R: A Language and Environment for Statistical Computing. Vienna, Austria: $\mathrm{R}$ Foundation for Statistical Computing.

Raboin, L.-M., Randriambololona, T., Radanielina, T., Ramanantsoanirina, A., Ahmadi, N., \& Dusserre, J. (2014). Upland rice varieties for smallholder farming in the cold conditions in Madagascar's tropical highlands. Field Crops Research, 169, 11-20. doi: 10.1016/J.FCR.2014.09.006

Raboin, L. M., Razafimahafaly, A. H. D., Rabenjarisoa, M. B., Rabary, B., Dusserre, J., \& Becquer, T. (2016). Improving the fertility of tropical acid soils: Liming versus biochar application? A long term comparison in the 
highlands of Madagascar. Field Crops Research, 199, 99-108. doi: 10.1016/j.fcr.2016.09.005

Rakotoson, T. (2014). Overcoming phosphate deficiency in flooded rice in Madagascar.

Richardson, A. E., Lynch, J. P., Ryan, P. R., Delhaize, E., Smith, F. A., Smith, S. E., ... Simpson, R. J. (2011). Plant and microbial strategies to improve the phosphorus efficiency of agriculture. Plant and Soil, 349(1-2), 121-156. doi: 10.1007/s11104-011-0950-4

Rose, T. J., Impa, S. M., Rose, M. T., Pariasca-Tanaka, J., Mori, A., Heuer, S., ... Wissuwa, M. (2013). Enhancing phosphorus and zinc acquisition efficiency in rice: a critical review of root traits and their potential utility in rice breeding. Annals of Botany, 112(2), 331-345. doi: 10.1093/aob/mcs217

Rowell, D. L. (2014). Soil Science : Methods \& Applications. Routledge.

Saito, K., Vandamme, E., Segda, Z., Fofana, M., \& Ahouanton, K. (2015). A Screening Protocol for Vegetative-stage Tolerance to Phosphorus Deficiency in Upland Rice. Crop Science, 55(3), 1223. doi: 10.2135/cropsci2014.07.0521

Satyanarayana, V., Vara Prasad, P. V., Murthy, V. R. K., \& Boote, K. J. (2002). Influence of integrated use of farmyard manure and inorganic fertilizers on yield and yield components of irrigated lowland rice. Journal of Plant Nutrition, 25(10), 2081-2090. doi: 10.1081/PLN-120014062

Schwertmann, U. (1964). Differenzierung der Eisenoxide des Bodens durch Extraktion mit AmmoniumoxalatLösung. Zeitschrift Für Pflanzenernährung, Düngung, Bodenkunde, 105(3), 194-202. doi: 10.1002/jpln.3591050303

Six, L., Smolders, E., \& Merckx, R. (2014). Testing phosphorus availability for maize with DGT in weathered soils amended with organic materials. Plant and Soil, 376(1), 177-192. doi: 10.1007/s11104-013-1947-y

Soil Science Division Staff. (2017). Soil Survey Manual (USDA Handb; C. Ditzler, K. Scheffe, \& H. C. Monger, Eds.). Washington D.C.: Government Printing Office.

Sposito, G. (1996). The environmental chemistry of aluminum (2nd ed.; G. Sposito, Ed.). Lewis Publishers.

Stoorvogel, J. J., Smaling, E. M. A., \& Janssen, B. H. (1993). Calculating soil nutrient balances in Africa at different scales. Fertilizer Research, 35(3), 227-235. doi: 10.1007/BF00750641

Thibaud, M. C., Morel, C., \& Fardeau, J. C. (1988). Contribution of phosphorus issued from crop residues to plant nutrition. Soil Science and Plant Nutrition, 34(4), 481-491. doi: 10.1080/00380768.1988.10416464

Turner, B. L. (2006). Organic phosphorus in Madagascan rice soils. Geoderma, 136(1-2), 279-288. doi: 10.1016/j.geoderma.2006.03.043

Vandamme, E., Rose, T., Saito, K., Jeong, K., \& Wissuwa, M. (2016). Integration of P acquisition efficiency, P utilization efficiency and low grain $\mathrm{P}$ concentrations into $\mathrm{P}$-efficient rice genotypes for specific target environments. Nutrient Cycling in Agroecosystems, 104(3), 413-427. doi: 10.1007/s10705-015-9716-3

Vandamme, E., Wissuwa, M., Rose, T., Dieng, I., Drame, K. N., Fofana, M., ... Saito, K. (2016). Genotypic Variation in Grain P Loading across Diverse Rice Growing Environments and Implications for Field P Balances. Frontiers in Plant Science, 7, 1435. doi: 10.3389/fpls.2016.01435

Wainaina, C. M., Inukai, Y., Masinde, P. W., Ateka, E. M., Murage, H., Kano-Nakata, M., ... Makihara, D. (2015). Evaluation of Cold Tolerance in NERICAs Compared with Japanese Standard Rice Varieties at the Reproductive Stage. Journal of Agronomy and Crop Science, 201(6), 461-472. doi: 10.1111/jac.12125

Walinga, I., Lee, J. J., Houba, V. J. G., Vark, W., \& Novozamsky, I. (1995). Plant Analysis Manual. Springer Netherlands.

Wissuwa, M., \& Ae, N. (2001). Genotypic variation for tolerance to phosphorus deficiency in rice and the potential for its exploitation in rice improvement. Plant Breeding, 120(1), 43-48. doi: 10.1046/j.14390523.2001.00561.x

Zhang, P., Zhong, K., Tong, H., Shahid, M. Q., \& Li, J. (2016). Association mapping for aluminum tolerance in a core collection of rice landraces. Frontiers in Plant Science, 7(OCTOBER2016). doi: 10.3389/fpls.2016.01415 
Table 1. Information of the six rice genotypes used in the field experiments.

\begin{tabular}{|c|c|c|c|c|c|c|c|}
\hline Genotype Name & Genus & $\begin{array}{l}\text { Varietal } \\
\text { subgroup }\end{array}$ & Region of Origin & Varietal type & PAE $^{a}$ & $\mathbf{R E}^{\mathrm{b}}$ & References \\
\hline NERICA 4 & $\begin{array}{c}\text { O. sativa } \times \\
\text { O. glaberrima }\end{array}$ & tropical japonica & West Africa & Modern & low & low & $\begin{array}{l}\text { De Bauw et al., 2019; Koide et al., } \\
\text { 2013; Mori et al., 2016; Saito et al., } \\
2015\end{array}$ \\
\hline CG 14 & O. glaberrima & - & West Africa & Traditional & high & low & $\begin{array}{l}\text { Koide et al. } 2013 \\
\text { Wissuwa (personal communication) }\end{array}$ \\
\hline DJ 123 & O. sativa & aus subspecies & Bangladesh & Traditional & high & high & Mori et al., 2016; Saito et al., 2015 \\
\hline Chomrong Dhan & O. sativa & $\begin{array}{l}\text { temperate } \\
\text { japonica }\end{array}$ & Nepal & Traditional & $N A$ & $N A$ & Raboin et al. 2014 \\
\hline FOFIFA 172 & O. sativa & tropical japonica & Madagascar & Modern & $N A$ & $N A$ & Raboin et al. 2014 \\
\hline FOFIFA 173 & O. sativa & tropical japonica & Madagascar & Modern & $N A$ & $N A$ & Raboin et al. 2014 \\
\hline
\end{tabular}

NA Data not available. aPhosphorus Acquisition Efficiency, expressed as total $\mathrm{P}$ uptake in mg at low $\mathrm{P}$ availability in the soil. ${ }^{\mathrm{b}}$ Root Efficiency, expressed as total

$\mathrm{P}$ uptake per unit root size (either root biomass in $\mathrm{g}$ or root surface area in $\mathrm{cm}^{2}$ ). 
Table 2. Information on soil properties of unamended (control) soil in the field and soil incubation experiments. Mean and standard deviations are presented when applicable ( $n=4$ for Field 1 and 2; $n=3$ for the incubation experiment). Field experiment 3 was conducted at the edge of Field experiment 2 , and hence soil properties are similar.

\begin{tabular}{|c|c|c|c|c|}
\hline Experiment & $\begin{array}{c}\text { Field experiment } \\
1\end{array}$ & $\begin{array}{c}\text { Field experiment } \\
2\end{array}$ & $\begin{array}{c}\text { Field experiment } \\
3\end{array}$ & $\begin{array}{l}\text { Incubation } \\
\text { experiment }\end{array}$ \\
\hline Start year & 2016 & 2017 & 2018 & 2019 \\
\hline Duration & 3 seasons & 2 seasons & 1 season & 99 days \\
\hline Coordinate & $\begin{array}{l}19^{\circ} 12^{\prime} 59.3^{\prime \prime S} \\
47^{\circ} 27^{\prime} 10.6^{\prime \prime E}\end{array}$ & $\begin{array}{l}19^{\circ} 13^{\prime} 01.5^{\prime \prime S} \\
47^{\circ} 27^{\prime} 09.2^{\prime \prime E}\end{array}$ & $\begin{array}{l}19^{\circ} 13^{\prime} 00.4^{\prime \prime S} \\
47^{\circ} 27^{\prime} 09.5^{\prime \prime E}\end{array}$ & $\begin{array}{l}19^{\circ} 12^{\prime} 59.3^{\prime \prime} \mathrm{S} \\
47^{\circ} 27^{\prime} 10.6^{\prime \prime} \mathrm{E}\end{array}$ \\
\hline \multicolumn{5}{|l|}{ Soil properties } \\
\hline Soil classification ${ }^{a}$ & Ferralsol & Ferralsol & Ferralsol & Ferralsol \\
\hline Bulk Density $\left(\mathrm{g} \mathrm{cm}^{3}\right)$ & 0.98 & - & - & - \\
\hline Soil texture ${ }^{b}$ & Silty clay & Clay & $\sim$ & $N A$ \\
\hline Sand (\%) & $1.93 \pm 1.66$ & $0.64 \pm 1.28$ & $\sim$ & $N A$ \\
\hline Silt (\%) & $50.8 \pm 2.6$ & $39.0 \pm 7.9$ & $\sim$ & $N A$ \\
\hline Clay (\%) & $47.2 \pm 2.9$ & $60.3 \pm 9.0$ & $\sim$ & $N A$ \\
\hline $\operatorname{SOC}^{c}(\%)$ & $3.0 \pm 0.5$ & $3.0 \pm 0.3$ & $\sim$ & $3.3 \pm 0.1$ \\
\hline Soil pH $\mathrm{CaCl2}^{d}$ & $4.3 \pm 0.1$ & $4.4 \pm 0.1$ & $\sim$ & $4.3 \pm 0.1$ \\
\hline $\mathrm{eCEC}^{\mathrm{e}}\left(\mathrm{cmol}_{\mathrm{c}} \mathrm{kg}^{-1}\right.$ soil) & $2.1 \pm 0.3$ & $1.7 \pm 0.2$ & $\sim$ & $2.3 \pm 0.1$ \\
\hline P-total ${ }^{f}$ (mg kg ${ }^{-1}$ soil) & $680 \pm 30$ & $550 \pm 10$ & $\sim$ & $620 \pm 10$ \\
\hline $\mathrm{N}$-total ${ }^{\mathrm{c}}$ (mg kg${ }^{-1}$ soil) & $2029 \pm 360$ & $1690 \pm 170$ & $\sim$ & $2220 \pm 90$ \\
\hline P-ox (mg kg ${ }^{-1}$ soil) & $26.7 \pm 4.1$ & $17.3 \pm 1.9$ & $\sim$ & $29.3 \pm 3.3$ \\
\hline Fe-ox ${ }^{g}$ (mg kg-1 soil) & $1940 \pm 130$ & $1620 \pm 80$ & $\sim$ & $1720 \pm 50$ \\
\hline Al-ox ${ }^{g}$ (mg kg-1 soil) & $2680 \pm 210$ & $2650 \pm 90$ & $\sim$ & $2670 \pm 601$ \\
\hline Mn-oxg (mg kg-1 soil) & $17.8 \pm 9.1$ & $10.6 \pm 4.9$ & $\sim$ & $21.9 \pm 1.2$ \\
\hline
\end{tabular}

\$Soil sampling location is indicated in this table, while incubation was performed in Belgium. aSoil classification (IUSS Working Group WRB, 2015). ' Soil texture based on particle size distribution (Soil Science Division Staff, 2017) determined by laser diffraction. 'Soil organic carbon and total $\mathrm{N}$ determined with elemental analyzer. ${ }^{\mathrm{d}} \mathrm{pH}(1: 10,24 \mathrm{~h})$ determined in $1 \mathrm{mM} \mathrm{CaCl}_{2}$. eEffective cation exchange capacity (eCEC) was determined in a $0.0166 \mathrm{M}$ cobalt hexamine (Cohex) extract (ISO, 2007), as the difference between total Co added and Co measured in the extract with inductively coupled plasma-optical emission spectrometry (ICP-OES). 'Total P determined in aqua-regia digests (Walinga, Lee, Houba, Vark, \& Novozamsky, 1995). gAmmonium-oxalate extractive $\mathrm{P}, \mathrm{Al}$, Fe and Mn (Schwertmann, 1964). 
Table 3. The agronomic $P$ efficiency (APE) [kg grain yield $\mathrm{kg}^{-1} \mathrm{P}$ application] of the mineral and organic $\mathrm{P}$ amendments in the three field experiments. Mean values with standard error are presented for each treatment, as also the overall mean and coefficient of variation (CV) within treatment.

\begin{tabular}{|c|c|c|c|c|c|c|c|c|c|}
\hline \multirow[b]{3}{*}{ Genotype } & \multicolumn{9}{|c|}{ Field Experiment 1} \\
\hline & \multicolumn{3}{|c|}{ Season 1 (2016) } & \multicolumn{3}{|c|}{ Season 2 (2017) } & \multicolumn{3}{|c|}{ Season 3 (2018) } \\
\hline & FYM & TSP & $P+F Y M$ & FYM & TSP & $P+F Y M$ & FYM & TSP & $\mathrm{P}+\mathrm{FYM}$ \\
\hline NERICA 4 & $18.2(7.3)$ & $12.3(5.7)$ & $13.5(5.1)$ & $78.8(6.2)$ & $13.1(2.0)$ & $68.9(10.3)$ & $81.8(8.9)$ & $70.3(13.8)$ & $69.3(7.2)$ \\
\hline CG 14 & $26.0(1.0)$ & $7.7(2.5)$ & $16.8(1.2)$ & $55.0(1.9)$ & $25.8(4.0)$ & $41.4(2.9)$ & $99.8(6.2)$ & $45.9(9.1)$ & $52.5(13.8)$ \\
\hline DJ 123 & $10.0(1.3)$ & $3.8(1.1)$ & $7.3(N A)$ & $62.4(10.5)$ & $9.1(2.2)$ & $28.4(3.2)$ & $75.1(23.9)$ & $54.9(6.8)$ & $59.8(4.1)$ \\
\hline Chomrong Dhan & $28.4(15.0)$ & $8.1(3.2)$ & $13.3(1.9)$ & $95.4(19.7)$ & $27.7(4.6)$ & $47.2(10.0)$ & $95.2(19.3)$ & $46.5(5.5)$ & $103.7(6.3)$ \\
\hline FOFIFA 172 & $31.3(6.0)$ & $9.6(2.1)$ & $N A$ & $67.7(15.0)$ & $46.2(5.8)$ & $83.1(4.0)$ & $72.6(13.9)$ & $49.5(16.3)$ & $85.6(12.0)$ \\
\hline FOFIFA 173 & $N A$ & $N A$ & $N A$ & $73.8(12.4)$ & $34.4(5.2)$ & $46.7(5.7)$ & $110.7(7.1)$ & $54.2(12.1)$ & $77.0(13.5)$ \\
\hline $\begin{array}{l}\text { Overall Mean } \\
\text { (SE) }\end{array}$ & $23.0(3.4)$ & $8.5(1.8)$ & $14.2(1.7)$ & $72.5(5.3)$ & $26.4(2.9)$ & $54.6(4.4)$ & $88.0(6.3)$ & $53.2(4.4)$ & $76.2(4.7)$ \\
\hline \multirow[t]{3}{*}{$\mathrm{CV}$} & 63.3 & 88.5 & 37.7 & 38.6 & 57.4 & 41.9 & 38.1 & 43.0 & 32.4 \\
\hline & \multicolumn{6}{|c|}{ Field Experiment 2} & \multicolumn{3}{|c|}{ Field Experiment 3} \\
\hline & \multicolumn{3}{|c|}{ Season 1 (2017) } & \multicolumn{3}{|c|}{ Season 2 (2018) } & \multicolumn{3}{|c|}{ Season 1 (2018) } \\
\hline Genotype & FYM & TSP & $\mathrm{P}+\mathrm{FYM}$ & FYM & TSP & $P+F Y M$ & $\begin{array}{l}\text { Lime+TSP } \\
\text { vs ctrl }\end{array}$ & & $\begin{array}{l}\text { Lime+TSP } \\
\text { vs Liming }\end{array}$ \\
\hline NERICA 4 & $40.6(5.4)$ & $14.3(4.0)$ & $29.1(5.2)$ & $38.8(9.3)$ & $40.1(4.5)$ & $72.9(9.2)$ & 87.9 (12.6) & & $N A$ \\
\hline CG 14 & $38.4(4.9)$ & $14.2(2.9)$ & $17.2(1.0)$ & $55.0(10.5)$ & $79.1(3.8)$ & $43.3(4.7)$ & $133.2(41.3)$ & & $23.2(41.3)$ \\
\hline DJ 123 & $24.5(3.0)$ & $7.1(1.4)$ & $14.9(1.8)$ & $41.8(5.5)$ & $35.2(4.3)$ & $64.3(6.5)$ & $60.6(13.6)$ & & $48.9(13.6)$ \\
\hline Chomrong Dhan & $51.9(6.2)$ & $31.2(5.1)$ & $47.6(2.9)$ & $65.7(9.3)$ & $80.1(10.7)$ & $93.3(9.1)$ & $123.0(15.9)$ & & 81.3 (15.9) \\
\hline FOFIFA 172 & $50.8(6.3)$ & $25.9(3.8)$ & $37.7(6.2)$ & $53.4(8.6)$ & $72.5(10.4)$ & $82.1(10.7)$ & $176.0(13.5)$ & & 168.5 (13.5) \\
\hline FOFIFA 173 & $34.2(7.1)$ & $26.4(5.1)$ & $24.4(6.4)$ & $95.7(13.4)$ & $76.3(15.3)$ & $99.0(5.1)$ & $111.9(29.2)$ & & $92.3(29.2)$ \\
\hline $\begin{array}{l}\text { Overall Mean } \\
\text { (SE) }\end{array}$ & $41.0(2.6)$ & $20.4(2.0)$ & $28.9(2.4)$ & $57.2(4.5)$ & $62.2(4.5)$ & $75.5(4.2)$ & $109.4(10.2)$ & & 94.4 (13.1) \\
\hline $\mathrm{CV}$ & 42.0 & 64.3 & 55.7 & 52.1 & 47.3 & 36.1 & 40.4 & & 52.1 \\
\hline
\end{tabular}


Table 4. Summary of rice grain yield, shoot $P$ uptake, and agronomic $P$ efficiency (APE) in the six field trials. Data include all treatments (including lime treatments) but exclude the zero yielding control treatments. Data show statistical comparison (Tuckey's HSD) for the least square means of the genotypes after fitting model Eqn. (1) that is presented in Table S3 (Supplementary Information). The p-values are assigned as $*_{* *}^{*}, \mathrm{p}<0.001 ; * *, \mathrm{p}<0.01 ;{ }^{*}, \mathrm{p}<0.05$. Means in the same column followed by the same character are not significantly different (Tukey's HSD, $\mathrm{p}<0.05$ ). The effect size (\% variance explained) was calculated by including year as fixed (not random) factor, while the models presented in Eqn. (1) (Table S3) present a mixed modelling with year as random factor.

\begin{tabular}{|c|c|c|c|}
\hline Genotype & $\begin{array}{c}\text { Grain yield } \\
{\left[\mathrm{t} \mathrm{ha}^{-1}\right]}\end{array}$ & $\begin{array}{l}\text { P uptake } \\
{\left[\mathrm{kg} \mathrm{P} \mathrm{ha}^{-1}\right]}\end{array}$ & $\begin{array}{c}\text { Agronomic } \mathrm{P} \text { efficiency (APE) } \\
{[\mathrm{kg} \text { grain yield }} \\
\left.\mathrm{kg}^{-1} \mathrm{P} \text { application }\right]\end{array}$ \\
\hline DJ 123 & $1.1^{d}$ & $2.8^{b}$ & $28^{b}$ \\
\hline CG 14 & $1.3^{\mathrm{cd}}$ & $2.8^{\mathrm{b}}$ & $38^{b}$ \\
\hline NERICA 4 & $1.6^{\mathrm{bc}}$ & $2.8^{\mathrm{b}}$ & $39^{b}$ \\
\hline FOFIFA 173 & $1.9^{\mathrm{ab}}$ & $3.2^{\mathrm{ab}}$ & $52^{\mathrm{a}}$ \\
\hline FOFIFA 172 & $2.1^{\mathrm{a}}$ & $3.5^{\mathrm{ab}}$ & $51^{\mathrm{a}}$ \\
\hline Chomrong Dhan & $2.2^{\mathrm{a}}$ & $3.7^{\mathrm{a}}$ & $55^{a}$ \\
\hline Factor & \multicolumn{3}{|c|}{$\%$ variance explained } \\
\hline Year & $18.0 * * *$ & $10.9 * * *$ & $31.9 * * *$ \\
\hline $\mathrm{P}$ application (kg ha-1) & $28.5^{* * *}$ & $43.2 * * *$ & $0.1^{\text {n.s. }}$ \\
\hline $\mathrm{CaCl}_{2}$-extractable $\mathrm{Al}$ in soil $\left(\mu \mathrm{g} \mathrm{L}^{-1}\right)$ & $1.4^{* * *}$ & $<0.1^{\text {n.s. }}$ & $2.2 * * *$ \\
\hline Geno & $5.6^{* * *}$ & $1.4^{*}$ & $7.3^{* * *}$ \\
\hline Geno $\times \mathrm{P}_{\mathrm{appl}}$ & $2.6 * * *$ & $1.5^{*}$ & $1.7^{*}$ \\
\hline Geno $\times \mathrm{Al}$ & $1.0^{*}$ & $0.5^{\text {n.s. }}$ & $1.2^{\text {n.s. }}$ \\
\hline Total model $\mathrm{R}^{2}$ & 0.57 & 0.57 & 0.45 \\
\hline
\end{tabular}




\section{Figure Captions}

Figure 1: Rice grain yields of Field Experiment 1 and Field Experiment 2, after 1, 2, or 3 seasons of continuous soil fertilization. Barplots are presented as mean with standard deviation. Treatment (Trt) effects are FYM application (FYM), mineral P fertiliser (TSP), and genotype (Geno), while complete crop failure was observed for the unamended control soil (Ctrl). The coefficient of variation of yield among genotypes is presented for each soil treatment in a box below the bars and was generally largest for the TSP treatment. Note that the scale of the $\mathrm{Y}$-axis is different for each year.

Figure 2: The total $P$ uptake in rice grain and straw at maturity in Field Experiment 1 and Field Experiment 2, after 1, 2, and 3 years of continuous soil fertilization. Barplots are presented as mean with standard deviation. Treatment (Trt) effects are FYM application (FYM), mineral P amendment (TSP), and genotype selection (Geno), while complete crop failure was observed for the unamended control soil (Ctrl). The coefficient of variation of the total $\mathrm{P}$ uptake among genotypes is presented for each soil treatment in a box below the bars and was generally largest for the TSP treatment. Note that the scale of the Y-axis is different for each year.

Figure 3: The grain yield and total P uptake at maturity in Field Experiment 3 (Lime and Lime+TSP). Barplots are presented as mean with standard deviation. The coefficient of variation among genotypes is given for each treatment (Trt) in a box below the bars.

Figure 4: The dynamics of (A) the soil $\mathrm{pH}$ (top), (B) $1 \mathrm{mM} \mathrm{CaCl} 2$ extractable $\mathrm{P}$ (middle), and (C) $1 \mathrm{mM} \mathrm{CaCl}_{2}$ extractable $\mathrm{Al}$ (bottom) of the soils incubated in laboratory conditions. Note the log scale of extractable solute concentrations. Soils were amended with four rates of FYM $\left(0,2.3,12.0,23.5,46.9 \mathrm{~g} \mathrm{FYM} \mathrm{kg}^{-1}\right.$ soil, $\mathrm{n}=3$ each), and incubated at $25^{\circ} \mathrm{C}$ without leaching. 